\title{
Kâr Payı Politikaları ile Pay Senedi Volatilitesi Arasındaki İlişki: BİST 50 Endeksinde Yer Alan Firmalar Üzerine Ekonometrik Bir Araştırma* $^{*}$
}

\section{ÖZET}

Çalışmada, BiST 50 endeksinde 2000-2019 döneminde işlem gören reel sektör firmalarının kâr payı politikaları ile pay senedi volatilitesi arasındaki ilişki panel veri analizi ile incelenmiştir. Çalışmada firmaların kâr payı politikalarının göstergesi olarak kâr payı getirisi ve kâr payı ödeme oranı bağımsız değişken olarak, pay senedi volatilitesi ise bağıml değişken olarak analize dahil edilmiştir. Analiz sonucunda, kâr payı ödeme oran ile pay senedi volatilitesi arasinda pozitif yönlü bir ilişki, kâr payı getirisi ile pay senedi volatilitesi arasında negatif yönlü bir iliş̧ki tespit edilmiştir. Analiz sonuçlarına göre kâr payı politikalarının pay senedi volatilitesini etkilediği, sinyal teorisi ve müşteri etkisi teorisinin geçerli olduğu söylenebilir.

Anahtar Kelimeler: Kar Payı Politikası, Volatilite, Pay Piyasası

JEL Sinıflandırması: C33, D53, G30

\section{The Relationship Between Dividend Policy and Stock Price Volatility: An} Econometric Application on Firms Listed in BIST 50 Index

\section{ABSTRACT}

In this study, the relationship dividend policy and stock volatility between the years 2000-2019 of the reel sector firms of the BIST 50 index was analyzed by panel regression analysis. In the study, while dividend yield and dividend payout ratio are included in the analysis as independent variables as indicators of the dividend policies of companies, stock volatility is included in the analysis as a dependent variable. As a result of the analysis, while a positive relationship was determined between the dividend payout ratio and stock volatility, $a$ negative correlation was determined between dividend yield and stock volatility. According to the findings of the study, it can be said that dividend policies affect stock volatility, signalling theory and customer affect theory are valid.

Keywords: Dividend Policy, Volatility, Stock Market

Jel Classification: C33, D53, G30

\footnotetext{
* Makale Gönderim Tarihi: 15.10.2020 , Makale Kabul Tarihi: 15.01.2021 , Makale Türü: Nicel Analiz

** Dr. Öğr. Üyesi, Şırnak Üniversitesi, İktisadi ve İdari Bilimler Fakültesi, tnurtopaloglu@sirnak.edu.tr,

Orcid ID: 0000-0002-0974-4896
} 


\section{GİRIŞ}

Kâr payı politikası, firmaların yıl boyunca faaliyetlerinden elde ettikleri kazançların tamamını ya da bir kısmını hissedarlara sahip oldukları pay oranında dağıtması veya yeniden yatırım firsatlarına yönlendirmesi anlamına gelmektedir. Kâr payı dağıtım politikaları sadece yöneticiler değil aynı zamanda yatırımcılar için de önem arz etmektedir. Yöneticilerden, günlük faaliyetlerde likiditeyi korumaları ve kâr payı politikaları ile gelecekteki sermaye yatırımları için finansman sağlamaları beklenmektedir. Yatırımcılar kâr payı ödemesine ilişkin bilgileri kullanarak yatırım yapacakları firmaların değerlerini değerlendirebilmektedir (Nguyen vd., 2019:124-125). Bir firmanın kâr payı ödemesi artırıldığında pay senedi fiyatı yükseldiği, tersi durumda kâr payı ödemesi azaltıldığında ise pay senedi fiyatında düşüş yaşandığı piyasalarda gözlemlenmiştir. Bu durum firma yönetiminin nakit akışları yüksek olmasa dahi, piyasadaki yatırımcıları nakit akışlarının yüksek olacağına inandırmak için de olsa kâr payı ödemelerini artırma olasılığı doğurabilmektedir (Ross vd., 2005:526). Bu kapsamda firmaların yatırımcılara sundukları kâr payı ödemeleri, şirkete olan talebi etkileyecektir. Bu durum firmaların pay fiyatlarında artış veya azalışa yol açabilecektir. Kâr payı politikaları piyasalarda beklentiyi artıracak ve pay fiyatlarında volatiliteye sebep olabilecektir (Nguyen vd., 2019:124-125).

Pay fiyatlarındaki volatilite yatırımcılar için yatırımlarında maruz kaldıkları risklerin bir göstergesidir. Yüksek volatilite yüksek riski, düşük volatilite ise düşük riski temsil eder ve bu tür paylara yatırım yapan yatırımcılar için teşvik edici ya da caydırıcı sonuçlar doğurabilmektedir (Agbatogun vd. 2019: 36). Dolayısıyla yatırımcilar piyasaya gelen bilgilere duyarlıdır ve kâr payı politikası ile pay senedi volatilitesi arasındaki ilişkinin araştııılması önem arz etmektedir. Literatürde kâr payı politikaları ile pay fiyatı ve volatilitesi arasındaki ilişkinin araştırıldığı çalışmaların sonuçlarında fikir birliğine ulaşılamamıştır. Bu doğrultuda çalışmada, BİST 50 endeksinde 2000-2019 döneminde devamlı olarak işlem gören reel sektör firmalarının kâr payı politikaları ile pay senedi volatilitesi arasındaki ilişkiyi araştırmak amaçlanmıştır. $\mathrm{Bu}$ doğrultuda ilk olarak teorik çerçeve açıklanmış, literatür taramasına yer verilmiş ve araştırmanın metodolojisine değinilmiştir. Son olarak analizler kapsamında elde edilen bulgular değerlendirilip yorumlanmıştır.

\section{TEORIKK ÇERÇEVE}

Finansal yönetimin amacı, kâr payı teorileri altında pay fiyatlarını maksimize ederek hissedarların beklentisini ve firma değerini maksimum yapmaktır (Diacogiannis, 1993: 623). Firmaların kâr payı dağııım politikalarının firma değeri üzerinde etkisine ilişkin bazı yaklaşımlar mevcuttur. İlgili yaklaşımlar aşağıda ayrıntılı olarak açıklanmaktadır.

Kâr payı ilintisizlik teorisi: Modigliani ve Miller, belirli varsayımlar altında, kâr payı ilintisizlik teorisini önermişlerdir. Teorilerinde firmaların yatırım kararları göz önüne alındığında kâr payı ödeme oranının sadece bir detay olduğunu ve firmaların pay fiyatı üzerinde herhangi bir etkisinin olmadığını bu nedenle hissedarların servetini etkilemeyeceğini savunmuşlardır. Firma değerinin, firmanın varlıklarının kazanma gücüne ve riskine göre değiştiğini ifade etmişlerdir (Van Horne ve Wachowicz 1997:484). Kâr payı ödemesinin firmanın değerini etkilemesinin bilgi etkisi, müşteri etkisi veya sinyal etkisi olduğunu öne sürmüşlerdir. 
Eldeki kuş teorisi: Linter (1962) ve Gordon (1963), kâr payı ödemelerin sermaye kazancından daha az risk içermesi ve kâr payı geliri elde etmenin sermaye kazancına göre daha belirli olmasından dolayı yatırımcıların kâr payı ödemesini sermaye kazancına tercih ettiğini öne sürmüşlerdir. Sonuç olarak, yatırımcılar yüksek kâr payı ödemesi yapan firmalara daha fazla değer verecektir. Buna ek olarak, kâr payı ödemesi yapan bir firmanın herhangi bir kâr payı ödemesi yapmayan bir firmaya kıyasla derecelendirme kuruluşlarından daha yüksek bir not alacaktır. Daha iyi bir derecelendirme ile firma, kredi kurumları kâr payı ödemesinin firmanın yükümlülüklerini yerine getirme kabiliyetine sahip olduğunu gösterdiğinden, sermaye piyasalarından daha kolay finansman sağlayabilecektir (M'rabet ve Boujjat, 2016: 472).

a) Kâr payları ilişskisizdir. (MM)

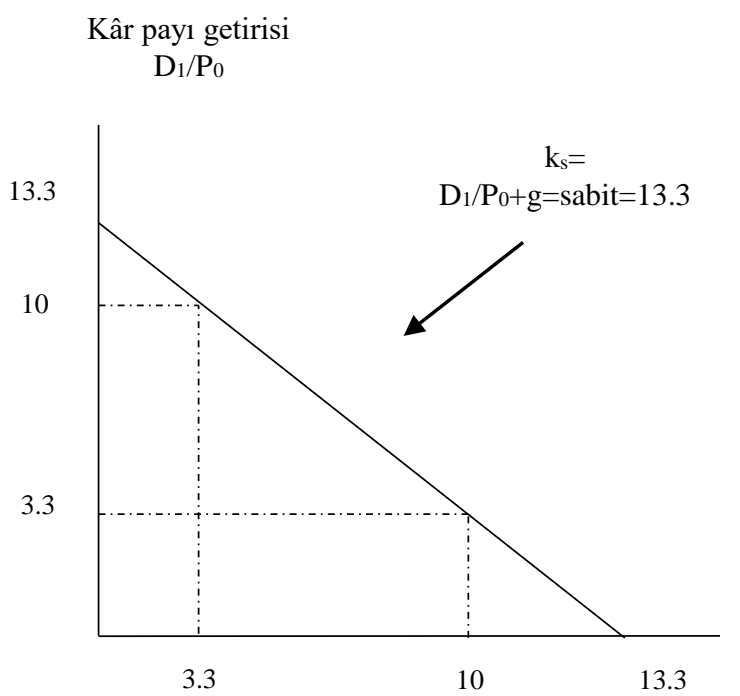

b) Kâr payları ilişkilidir. Yatırımcılar kâr payı ödemesinden hoşlanırlar. (GL)

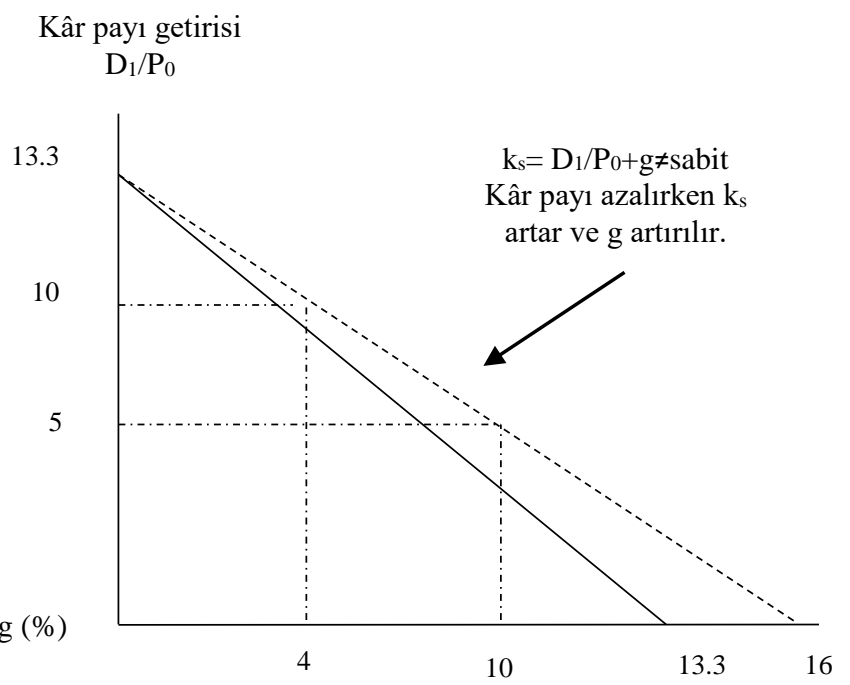

Şekil 1. Modigliani- Miller ve Gordon-Linter Temettü Hipotezleri Kaynak: (Brigham, 1999: 269)

Şekil 1'de Modigliani-Miller ve Gordon-Linter görüşleri gösterilmektedir. MM'e göre firmanın herhangi bir kâr payı politikası için $\mathrm{k}_{\mathrm{s}}$ 'si vardır. Bu nedenle toplam denge kârının, $\mathrm{k}_{\mathrm{s}}$ 'nin tamamen beklenen sermaye kazanc1 (yatay eksen kesim noktas1 \%13,3) olarak bütünüyle kâr payı getirisi (dikey eksen kesim noktası \%13,3) olarak sabit bir değer biçiminde olduğu varsayılmaktadır. Gordon ve Linter kâr payı gelirinin, muhtemel sermaye kazancina göre daha belirli olmasından dolayı yatırımcıların kâr payı ödemesini sermaye kazancına tercih ettiğini iddia etmektedirler. Gordon-Linter kâr payı getirisinde \%1'lik düşürmeyi dengelemek için \%1'den daha büyük ek büyümenin gerekli olduğunu öne sürmüşlerdir. Şekil b'de hiç kâr payı ödenmediğinde $\mathrm{k}_{\mathrm{s}} \% 16$ olacaktır. Burası kâr payı getirisinin sıfir olduğu noktadır (Brigham, 1999: 268).

Vergi farklılı̆̆ı teorisi: Farrar ve Selwyn (1967) tarafından geliştirilen model yatırımcıların vergi sonrası geliri en üst düzeye çıkarmak istediğini varsaymaktadır. Kısmi bir denge çerçevesinde yatırımcıların, firma dağıtımlarını kâr payı veya sermaye kazancı olarak alma seçenekleri vardır (Frankfurter ve Wood, 2002:112). Kâr payı kazancı ve sermaye kazancı vergilendirilmesi farklılık göstermekte bu doğrultuda modele göre sermaye kazanc1, kâr payı ödemesine tercih edilmelidir. Kâr payı kazancı hemen vergilendirilirken, sermaye 
kazanc1 pay senedi satıldıktan sonra vergilendirilmektedir. Bu farklı vergilendirmeye dayanarak kurumsal yatırımcılar vergilendirmeyi daha ileriki bir tarihte ödemeyi tercih ederek sermaye kazancını kâr payı ödemesine tercih edeceklerdir (Dhaliwal vd., 1999: 179).

Sinyal teorisi: Piyasalar etkin olmadığında, yatırımcılar ve firma yöneticileri arasında asimetrik bilgi dağılımı mevcuttur. Bu nedenle sinyal teorisi, kâr payı politikalarına ilişkin bilgilerin firmanın gelecekteki nakit akışları hakkında bilgi verdiğini belirtmektedir. Teoriye göre bilgi asimetrisi ile kâr payı politikaları arasında pozitif yönlü ilişki vardır. Asimetrik bilgi seviyesi ne kadar yüksek olursa, kâr payının firmanın gelecekteki beklentilerine olan duyarlılığı o kadar yüksek olmaktadır. Bu doğrultuda kâr payı dağıtımlarının bilgi verme özelliği pay senedi fiyatlarını etkilemektedir (Dionne ve Ouderni, 2001:187).

Temsil teorisi: Hissedarlar, yöneticilerin kendi servetlerini maksimize etmesini beklerken, firmaya borç verenler ise kendi borçlarının ödenmesi beklentisi içerisindedir. $\mathrm{Bu}$ durum temsil maliyetlerine sebep olmaktadır. Firma kâr payı ödemesi yapmayarak, borcunu ödeme yoluna gider ise hissedarların servetinden borç verene ya da tam tersi kâr payı ödemesi yaparsa borç verenin servetinden hissedarlara transfer yapmış olmaktadır. Her iki durumda da kâr payı kararları hissedar ve borç veren arasında çıkar çatışmasına ve maliyete sebep olmaktadir (Ross vd., 2005:521).

Müşteri etkisi teorisi: Firmaların uyguladığı kâr payı politikaları yatırımcıları etkilemektedir. Düşük vergi aralığında bulunan yatırımcılar veya cari nakit akışına ihtiyaç duyan vergiden muaf kuruluşlar, yüksek kâr payı dağıtan firmalara yatırım yapma eğilimindeyken, yüksek gelire sahip yatırımcılar ise vergiden kaçmak için düşük kâr payı dağıtan veya hiç dağıtmayan firmalara yatırım yapmaktadırlar (Hooi vd., 2015:226). Yatırımcilar bu durumda kendi tercihlerine uygun olan firmalara yatırım yapacaklardır. Dolayısıyla kâr payı politikaları pay senedi fiyatını etkileyecektir.

Tablo 1. Kar Payı Politikası ve Pay Senedi Fiyatı İlişkisi Teorik Literatür Özeti

\begin{tabular}{|c|c|c|c|}
\hline Araştırmacı & Teori & Yll & Bulgu \\
\hline $\begin{array}{l}\text { Modigliani ve } \\
\text { Miller }\end{array}$ & $\begin{array}{l}\text { Kâr payı ilintisizlik } \\
\text { teorisi }\end{array}$ & 1961 & $\begin{array}{l}\text { Kâr payı ödeme oranının pay senedi fiyatı üzerinde } \\
\text { etkisi yoktur. }\end{array}$ \\
\hline Gordon ve Linter & Eldeki kuş teorisi & 1963 & $\begin{array}{l}\text { Kâr payı ödemesi sermaye kazancından daha belirli } \\
\text { olduğu için yatırımcılar yatırım kararlarında kâr } \\
\text { payı ödemesini dikkate alacaktır. Bu durum pay } \\
\text { fiyatlarını ve firma değerini etkileyecektir. }\end{array}$ \\
\hline Farrar ve Selwyn & Vergi farklılığ 1 teorisi & 1967 & $\begin{array}{l}\text { Kâr payı kazancı hemen vergilendirilirken, } \\
\text { sermaye kazancı pay senedi satıldıktan sonra } \\
\text { vergilendirilmektedir. Yatırımcılar bu nedenle } \\
\text { sermaye kazancını tercih edeceklerdir. Bu durum } \\
\text { pay fiyatlarını ve firma değerini etkileyecektir }\end{array}$ \\
\hline Linter & Sinyal teorisi & 1956 & $\begin{array}{l}\text { Kâr payı politikalarının bilgi verme özelliği, pay } \\
\text { senedi fiyatını etkilemektedir. }\end{array}$ \\
\hline Jensen ve Meckling & Temsil teorisi & 1976 & $\begin{array}{l}\text { Firmaların kâr payı ödeme kararları yöneticiler ve } \\
\text { hissedarlar arasında çıkar çatışmasına dolayısıyla } \\
\text { temsil maliyetlerine sebep olmaktadır. }\end{array}$ \\
\hline Pettit & Müşteri Etkisi Teorisi & 1977 & $\begin{array}{l}\text { Yatırımcılar kâr payı politikaları kendi tercihlerine } \\
\text { uygun olan firmalara yatırım yapmaktadır. Bu } \\
\text { nedenle kâr payı politikaları pay senedine olan } \\
\text { talebi dolayısıla fiyatı etkilemektedir. }\end{array}$ \\
\hline
\end{tabular}

Kaynak: Konuya ilişkin kaynaklardan derlenmiştir. 


\section{LITERATÜR TARAMASI}

Kâr payı politikası ile pay senedi volatilitesi arasındaki ilişkiyi araştıran ilk çalışmalardan birisi Baskin tarafından 1989 yılında yapılmıştır. Baskin çalışmasında 19671986 döneminde 2344 ABD firması üzerinde yaptığı araştırma sonucunda kâr payı getirisi ile pay senedi volatilitesi arasında negatif ilişki tespit etmiştir. Ardından uluslararası yazında kâr payı politikaları ile pay senedi volatilitesi arasındaki ilişkiyi araştıran birçok çalışma yapılmıştır bu çalışmalardan bazıları kronolojik sıraya göre aşağıda verilmektedir.

Allen ve Rachim (1996), 1972-1985 döneminde Avusturalya’da faaliyet gösteren 173 firma üzerinde kâr payı politikaları ile pay senedi volatilitesi arasındaki ilişkiyi araştırmışlardır. Yaptıkları analiz sonucunda Baskin'in (1989) ABD uygulamasının sonuçlarının aksine, kâr payı getirisi ile pay senedi fiyatı volatilitesi arasında ilişki olduğuna dair kanıt bulamamışlardır.

Hussainey vd., (2011), çalışmalarında İngiltere hisse senedi piyasasında kâr payı politikası ile pay senedi volatilitesi arasındaki ilişkiyi araştırmışlardır. Çoklu regresyon analiz yöntemini kullandıkları araştırmada, kâr payı getirisi ile pay senedi volatilitesi arasında pozitif, kâr payı ödeme oranı ile pay senedi volatilitesi arasında negatif ilişki tespit etmişlerdir.

Hashemijoo ve Ardekani (2012), çalışmalarında Malezya piyasasında işlem gören 84 şirketten oluşan örneklem üzerinde 2005-2010 döneminde, kâr payı getirisi ve ödemesi ile pay senedi volatilitesi arasındaki ilişkiyi araştırmışlardır. Panel veri analiz yöntemini kullandıkları çalışmada kâr payı getirisi ve ödemesi ile pay senedi volatilitesi arasında negatif ilişki tespit etmişlerdir.

Habib vd., (2012), Karachi menkul kıymetler borsasında kâr payı politikası ile pay senedi volatilitesi arasındaki ilişkiyi araştırmışlardır. Yaptıkları panel veri analizi sonucunda, kâr payı getirisi ile pay senedi volatilitesi arasında pozitif, kâr payı ödeme oranı ile pay senedi volatilitesi arasında negatif ilişki tespit etmişlerdir. Kâr payı politikalarının, pay senedi fiyatını etkilemesinin nedeni olarak sinyal etkisini öne sürmüşlerdir.

Ramadan (2013), çalışmasında 2000-2011 döneminde Amman borsasında işlem gören 77 sanayi işletmesi üzerinde kâr payı politikaları ile pay senedi volatilitesi arasındaki ilişkiyi araştırmıştır. En küçük kareler yöntemini kullanarak yaptığı analiz sonucunda kâr payı politikası ile pay senedi volatilitesi arasında negatif yönlü ilişki tespit etmiştir. Kâr payı ödemesi arttığında pay senedi fiyatının istikrarlı seyir izlediğini ve volatiliteyi dolaysıyla riski düşürdüğü sonucuna ulaşmıştır.

Lashgari ve Ahmadi (2014), Tahran menkul kıymetler borsasında işlem gören 51 şirket üzerinde kâr payı politikası ile pay senedi volatilitesi arasındaki ilişkiyi 2007-2012 döneminde araştırmışlardır. Yaptıkları panel veri analizi sonucunda kâr payı ödeme oranı ile pay senedi volatilitesi arasında negatif ilişki, aktif büyüme oranı ile pay senedi volatilitesi arasında pozitif yönlü ilişki tespit etmiş̧lerdir

Al-Shawawreh (2014), çalışmasında Ürdün borsasında işlem gören dört sektörü temsil eden 53 firma üzerinde 2001-2013 döneminde kâr payı politikaları ile pay senedi volatilitesi 
arasındaki ilişkiyi incelemiştir. Yapılan analiz sonucunda kâr payı ödemesi ile pay senedi volatilitesi arasında negatif yönlü, kâr payı getirisi ile pay senedi volatilitesi arasında çok zayıf pozitif yönlü ilişki tespit edilmiştir.

Hooi vd., (2015), Kuala Lumpur borsasında işlem gören 319 firmanın kâr payı politikası ile pay senedi volatilitesi arasındaki ilişkiyi incelemişlerdir. Yapılan analiz sonucunda kâr payı ödemesi ve kâr payı getirisi ile pay senedi volatilitesi arasında istatistiksel olarak anlamlı ve negatif yönlü ilişki tespit etmişlerdir.

Jahfer ve Mulafara (2016), çalışmalarında Sri Lanka borsasında, 2009-2013 döneminde işlem gören finansal olmayan firmalar üzerinde kâr payı politikası ile pay senedi volatilitesi arasındaki ilişkiyi araştırmışlardır. Çoklu regresyon modeli ile yaptıkları analiz sonucunda kâr payı getirisi ile pay senedi volatilitesi arasında pozitif yönlü ilişki tespit etmiş̧lerdir. Ayrıca kontrol değişkeni olarak kullandıkları firma büyüklüğü arttıkça volatilitenin düştüğü sonucuna ulaşmışlardır.

Yar Khan vd., (2017), çalışmalarında Pakistan piyasasında tekstil, kimya ve şeker sektöründe işlem gören 42 firmanın 2006-2007 dönemi için kâr payı politikaları ile pay senedi volatilitesi arasındaki ilişkiyi araştırmışlardır. Kâr payı ödeme oranı ve kâr payı getirisinin bağımsız değişken pay senedi volatilitesinin bağımlı değişken olarak alındığı analiz sonucunda kâr payı ödeme oranı ve kâr payı getirisi ile pay senedi volatilitesi arasında pozitif yönlü ilişki tespit edilmiştir. Ayrıca kontrol değişkeni olarak aldıkları firma büyüklüğü ve kaldıraç oranı ile pay senedi volatilitesi arasında pozitif yönlü ilişki tespit etmişlerdir.

Cristea ve Cristea (2018), çalışmalarında, Bükreş menkul kıymetler borsasında işlem gören finansal olmayan firmalar üzerinde 2002-2017 döneminde kâr payı politikalarının pay senedi volatilitesine olan etkisini araştırmışlardır. Çoklu regresyon analizi sonucunda kâr payı getirisi ile pay senedi volatilitesi arasında negatif yönlü iliş̧i tespit etmişlerdir. Kâr payı getirisi ne kadar düşük ise riskin o kadar yükseldiği sonucuna ulaşmışlardır.

Haque vd., (2018), Bangladeş Dhaka borsasında işlem gören 35 firmanın 2004-2014 dönemi verileri ile kâr payı politikaları ile pay senedi volatilitesi arasındaki ilişsi araştııılmıştır. İlişkiyi analiz etmek için kullanılan çoklu regresyon analizi sonucunda kâr payı getirisi ile pay senedi volatilitesi arasında negatif, kâr payı ödeme oranı ile pay senedi volatilitesi arasında pozitif yönlü ilişsi tespit edilmiştir.

Nguyen vd., (2019), çalışmalarında 2011-2016 döneminde Ho Chi Minh Menkul Kıymetler Borsası'nda işlem gören 141 firmanın verileri ile kâr payı politikaları ile pay senedi volatilitesi arasındaki ilişkiyi araştırmışlardır. Panel veri analizi yöntemi kullandıkları çalışmanın sonucunda kâr payı ödemesi ve kâr payı getirisi ile pay senedi volatilitesi arasında negatif yönlü ilişki tespit etmişlerdir.

Nguyen vd., (2020), çalışmalarında Vietnam'daki Ho Chi Minh Menkul Kıymetler Borsası'nda (HOSE) işlem gören firmaların kâr payı politikası ile pay senedi fiyat volatilitesi arasındaki ilişkiyi incelemişlerdir. 2009-2018 döneminde 260 firmanın verileriyle yaptıkları panel veri analizi sonucunda kâr payı getirisi ile pay senedi volatilitesi arasında pozitif, kâr payı ödeme oranı ile pay senedi volatilitesi arasında negatif yönlü ilişki tespit etmişlerdir. 
Ulusal yazında kâr payı politikaları ile pay senedi volatilitesi arasındaki ilişkiyi araştıran çalışma sayısı sınırlı olup, kar pay politikaları ile pay senedi getirisi ve fiyatı arasındaki ilişkiyi araştıran çalışmalar mevcuttur. İlgili çalışmalardan bazıları kronolojik sıralamaya göre aşağıda verilmiştir.

Günalp vd., (2010), çalışmalarında nakit kâr payı ödeme bilgisinin pay senedi getirisi üzerindeki etkisini araştırmışlardır. Bu doğrultuda 2003-2007 döneminde İMKB'de işlem gören 83 firmanın nakit kâr payı ödemesi ve pay senedi fiyatlarına ilişkin veriler kullanılarak regresyon analizi yapılmıştır. Yapılan analiz sonucunda pay başına nakit temettü oranı ile pay senedi fiyatı arasında istatistiksel olarak anlamlı ve negatif yönlü ilişki tespit edilmiştir.

Kar vd., (2012), çalışmalarında kar dağıtımı ile pay senedi değeri arasındaki ilişkiyi 2005-2010 döneminde spor hizmetleri alanında faaliyet gösteren firmalar üzerine araştırmışlardır. Yapılan korelasyon analiz sonuçlarına göre kar dağıtımı ile pay senedi değeri arasında istatistiksel olarak anlamlı pozitif yönlü ilişki tespit edilmiştir.

Kaderli ve Başkaya (2014), çalışmalarında firmaların dağıtacağı kar paylarına ilişkin duyurular ile firmanın getiri oranı arasındaki ilişkiyi araştırmışlardır. Araştırma 2009-2010 yılları arasında istikrarlı olarak nakit kâr payı ödeyen firmalar üzerine olay etüdü yöntemiyle yapılmıştır. Araştırmanın sonucunda kâr payı duyurularının pay senedi fiyatını etkilediği sonucuna ulaşılmıştır.

Gürel ve Bayazıtlı (2017), çalışmalarında Türkiye'deki firmaların dağıttıkları nakit kar paylarının hisse senedi getirileri üzerindeki etkisini araştırmışlardır. Çalışmalarında kâr payı dağıtan ve dağıtmayan firmalardan ayrı ayrı portföyler oluşturmuşlardır. Araştırma sonucunda kâr payı verimleri yüksek olan portföylerin getirilerinin daha yüksek olduğunu tespit etmişlerdir.

Eraslan ve Koç (2017), çalışmalarında kâr payı ödemeleri ile hisse başına kar arasındaki ilişkiyi araştırmışlardır. 2005-2015 döneminde Borsa İstanbul çimento sektöründe faaliyet gösteren 15 firma verileri ile yaptıkları panel veri analizi sonucunda kâr payı ödemeleri ile hisse başına kâr arasında pozitif yönlü ilişki tespit edilmiştir.

Süsay ve Tanrıöven (2018), çalışmalarında kâr payı dağıtımlarının pay senedi fiyatına olan etkisini araştırmışlardır. BİST 100 endeksinde işlem gören finansal ve sportif olmayan firmaların 2010-2017 dönemi verileri ile yaptıkları Wilcoxon Signed Rank Test sonuçlarına göre kâr payı dağıtımının pay senedi fiyatı üzerinde etkisi olduğunu ve nakit kâr payı dağıtımının etkisinin diğer kâr payı dağıtım türlerinden daha fazla olduğunu tespit etmişlerdir.

Sakarya vd., (2018), çalışmalarında firmaların kâr payı dağıtımına ilişkin duyuruları ile ilgili firmanın getiri oranı arasındaki ilişkiyi ortaya koymayı amaçlamışlardır. Bu amaçla, 2016 yılında kâr payı duyurusu yapan çimento sektöründe faaliyet gösteren BİST'te işlem gören firmalar üzerinde Olay çalışması yöntemiyle ilişkiyi araştırmışlardır. Araştırmanın sonucunda kâr payı ödeme duyurularının firmaların pay senedi fiyatlarını etkilediği sonucuna ulaşmışlardır.

Zor ve Küçük (2019), çalışmalarında kâr payı dağıtım duyuruları ile pay senedi fiyatı ilişkisini araştırmışlardır. BIST-100 endeksi üzerine 2010-2016 döneminde olay analizi 
kullanarak yaptıkları araştırmada firmanın kâr payı dağıtmayacağı yönünde yapılan duyuruların pay senedi fiyatı üzerinde negatif anormal getiriye neden olduğunu tespit etmişlerdir.

\section{METODOLOJI}

Çalışmada metodoloji başlığı altında araştırmanın amacı, kapsamı, kısıtları, veri seti, yöntemi, analiz sonuçları ve sonuçların değerlendirilmesine yer verilmiştir.

\subsection{Araştırmanın Amacı ve Kapsamı}

Çalışmada, BİST 50 endeksinde 2000-2019 döneminde devamlı olarak işlem gören reel sektör firmaların kâr payı politikaları ve pay senedi volatilitesi arasındaki ilişkinin ortaya çıkarılması amaçlanmıştır. Çalışmada analize dahil edilen firmalar Tablo 2'de gösterilmektedir.

Tablo 2. BİST 50 Endeksinde Yer Alan ve Analize Dahil Edilen Firmalar

\begin{tabular}{|c|c|c|}
\hline Sıra No & Firma Adı & $\begin{array}{c}\text { BÍST } \\
\text { Kodu }\end{array}$ \\
\hline 1 & Anadolu Cam Sanayii A.Ş. & ANACM \\
\hline 2 & Arçelik A.Ş. & ARCLK \\
\hline 3 & Aselsan Elektronik Sanayi ve Ticaret A.Ş. & ASELS \\
\hline 4 & Enka İnşaat ve Sanayi A.Ş. & ENKAI \\
\hline 5 & Ereğli Demir ve Çelik Fabrikaları T.A.Ş. & EREGL \\
\hline 6 & Ford Otomotiv Sanayi A.Ş. & FROTO \\
\hline 7 & Tofaş Türk Otomobil Fabrikaları A.Ş. & TOASO \\
\hline 8 & Trakya Cam Sanayii A.Ş. & TRKCM \\
\hline 9 & Tüpraş-Türkiye Petrol Rafinerileri A.Ş. & TUPRS \\
\hline 10 & Ülker Bisküvi Sanayi A.Ş. & ULKER \\
\hline
\end{tabular}

Çalışmada kâr payı politikası ve pay senedi getiri volatilitesi arasındaki ilişkiyi ortaya çıkarabilmek için bağımsız ve bağımlı değişkenlere ilişsin kullanılan ikincil veriler, www.finnet.com.tr veri tabanından sağlanmıştır.

\subsection{Araştırmanın Kısıtları}

Çalışmada, BİST 50 endeksinde 2000-2019 döneminde devamlı olarak işlem gören reel sektör firmaların kâr payı politikaları ve pay senedi volatilitesi arasındaki ilişki araştırılmış olup araştırmaya finansal kuruluşlar, holding ve yatırım ortaklıkları dahil edilmemiştir. Ayrıca BİST 50 endeksinde reel sektör firması olarak yer almasına rağmen çalışmanın bağımsız değişkenleri olan kâr payı getirisi ve kâr payı ödeme oranı verilerine ulaşılamamasından dolayı analize dahil edilemeyen firmalar, Kardemir Karabük Demir Çelik Sanayi ve Ticaret A.Ş., Migros Ticaret A.Ş., Sasa Polyester Sanayi A.Ş., Türk Hava Yolları A.O., Vestel Elektronik Sanayi ve Ticaret A.Ş. ve Yataş Yatak ve Yorgan Sanayi ve Ticaret A.Ş. olmuştur. 


\subsection{Araştırmanın Yöntemi, Veri Seti, Test Edilen Modeller ve Kurgulanan Hipotezler}

Çalışmada, bağımsız değişken olarak kâr payı getirisi ve kâr payı ödeme oranı, bağımlı değişken olarak ise pay senedi volatilitesi panel regresyon modeline literatürde konuya ilişkin çalışmalar doğrultusunda dahil edilmiştir. Çalışmada elde edilen bulguyu doğrudan etkilediği ve modelin anlamlılığını yükselttiği düşünülerek kontrol değişkeni eklenmemişstir. Analize dahil edilen değişkenlerin hesaplanma şekilleri aşağıda verilmektedir.

Pay senedi volatilitesi: Panel regresyon modeline bağımlı değişken olarak dahil edilmiştir. Analiz kapsamında aşağıdaki formülde gösterildiği üzere her yıl için varyans hesaplanmış ve karekökü alınmıştır Baskin (1989), Haque vd., (2018), Cristea ve Cristea (2018), Nguyen (2019), Nguyen (2020).

$\mathrm{PSV}=\sqrt{\frac{\sum_{i=1}^{\mathrm{n}}\left(\frac{H i-L i}{(H i \hat{i}-L i) / 2}\right)^{2}}{n}}$ y1l say1s1

$H i=\mathrm{i}$ yılı için en yüksek pay senedi fiyatı, $L i=\mathrm{i}$ yılı için en düşük pay senedi fiyatı, $n=$

Kâr payı getirisi: Panel regresyon modeline bağımsız değişken olarak dahil edilen kâr payı getirisi aşağıdaki formülde gösterildiği üzere hissedarlara ödenen nakit kâr payı tutarının, her bir firmanın piyasa değerine bölünmesiyle hesaplanmıştır Cristea ve Cristea (2018), Haque vd., (2018), Nguyen (2019), Nguyen (2020).

$\mathrm{KG}=\frac{\sum_{t=1}^{\mathrm{n}}(D i / M V i)}{n}$

$D i=i$ yılı için kâr payı getirisi, $M V i=i$ yılı piyasa değeri, $n=\mathrm{y} 1$ sayısı

Kâr payı ödeme oranı: Çalışmada bir diğer bağımsız değişken olarak analize dahil edilen kâr payı ödeme oranı hissedarlara ödenen nakit kâr payının, net dönem karına bölünmesiyle aşağıdaki formül ile hesaplanmıştır Cristea ve Cristea (2018), Haque vd., (2018), Nguyen (2019), Nguyen (2020).

$\mathrm{KÖO}=\sum_{i=1}^{n} \frac{(D i / E i)}{n}$

Di=i yılı için hissedarlara ödenen nakit kâr payı, $E i=i$ yılı için net dönem kârı, $n=y 11$ sayis1

Çalışmada kullanılan değişkenler kapsamında oluşturulan regresyon modeli aşağıdaki gibi kurgulanmıştır.

$\mathrm{PSV}_{\mathrm{it}}=\alpha_{\mathrm{i}}+\beta_{1} \mathrm{KG}_{\mathrm{it}}+\beta_{2} \mathrm{KÖO}_{\mathrm{it}}+\varepsilon_{\mathrm{i}}$

Kurgulanan model doğrultusunda sınanan hipotezler aşağıdaki gibidir. 


\section{Hipotez 1}

$\mathrm{H}_{0}$ : Kâr payı getirisi ile pay senedi volatilitesi arasında ilişki yoktur.

$\mathrm{H}_{1}$ : Kâr payı getirisi ile pay senedi volatilitesi arasında ilişki vardır.

\section{Hipotez 2}

Ho: Kâr payı ödeme oranı ile pay senedi volatilitesi arasında ilişki yoktur.

$\mathrm{H}_{1}$ : Kâr payı ödeme oranı ile pay senedi volatilitesi arasında ilişki vardır.

\subsection{Araştırmanın Bulguları ve Değerlendirilmesi}

Çalışmada kâr payı dağıtım kararları ile pay senedi volatilitesi arasındaki ilişsi araştırılmaktadır. Bu kapsamda gerçekleştirilen panel veri analizi sonucunda elde edilen bulgular ve değerlendirmeler aşağıdaki tablolarda gösterilmektedir. Analize dahil edilen değişkenlere ilişkin tanımlayıcı istatistikler Tablo 3 'te gösterilmektedir.

Tablo 3. Tanımlayıcı İstatistikler

\begin{tabular}{|c|c|c|c|}
\hline & PSV & KG & KÖO \\
\hline Ortalama & 4,062234 & 3,825255 & 35,41429 \\
\hline Medyan & 0,107974 & 2,701500 & 28,12650 \\
\hline Maksimum & 243,3779 & 25,91700 & 114,2290 \\
\hline Minimum & 0,000137 & 0,000000 & 0,000000 \\
\hline Std. Sapma & 20,02622 & 3,960477 & 30,22557 \\
\hline Çarpıklık & 9,466151 & 1,843512 & 0,521761 \\
\hline Basıklık & 106,4822 & 8,071257 & 2,157065 \\
\hline Jarque-Bera & 92225,03 & 327,5982 & 14,99564 \\
\hline Olasılık & 0,000000 & 0,000000 & 0,000554 \\
\hline Gözlem & 200 & 200 & 200 \\
\hline
\end{tabular}

Tablo 3'te yer alan tanımlayıcı istatistikler incelendiğinde analizde bağımlı değişken olarak yer alan pay senedi volatilitesi (PSV) değerleri ortalama 4,06, maksimum 243,37 ve minimum ise 0,00 olarak gerçekleşmiştir. Çalışmanın bağımsız değişkenleri incelendiğinde kâr payı getirisi $(\mathrm{KG})$ değerleri ortalama 3,82, maksimum 25,91 ve minimum ise 0,00 olarak, kar payı ödeme oranı (KÖO) değerleri ise ortalama 35,41, maksimum 114,22 ve minimum ise 0,00 olarak gerçekleşmiştir. Değişkenlere ilişkin basıklık ve çarpıklık katsayıları incelendiğinde kalın kuyruk ve sağa çarpık yapı sergilediği söylenebilmektedir. Ek olarak her üç değişkenin de J-B olasılık değeri, kritik değer olan 0,05'ten küçük olduğu gözlemlenmekte ve serilerin normal dağılım sergilediğini ifade eden yokluk hipotezi reddedilmektedir. $\mathrm{Bu}$ kapsamda öncelikle değişkenler arasında çoklu doğrusal bağlantı sorununun olup olmadığ1 incelenmiştir. Değişkenlere ilişkin serpilme diyagramları aşağıda Şekil 2'de gösterilmektedir. 

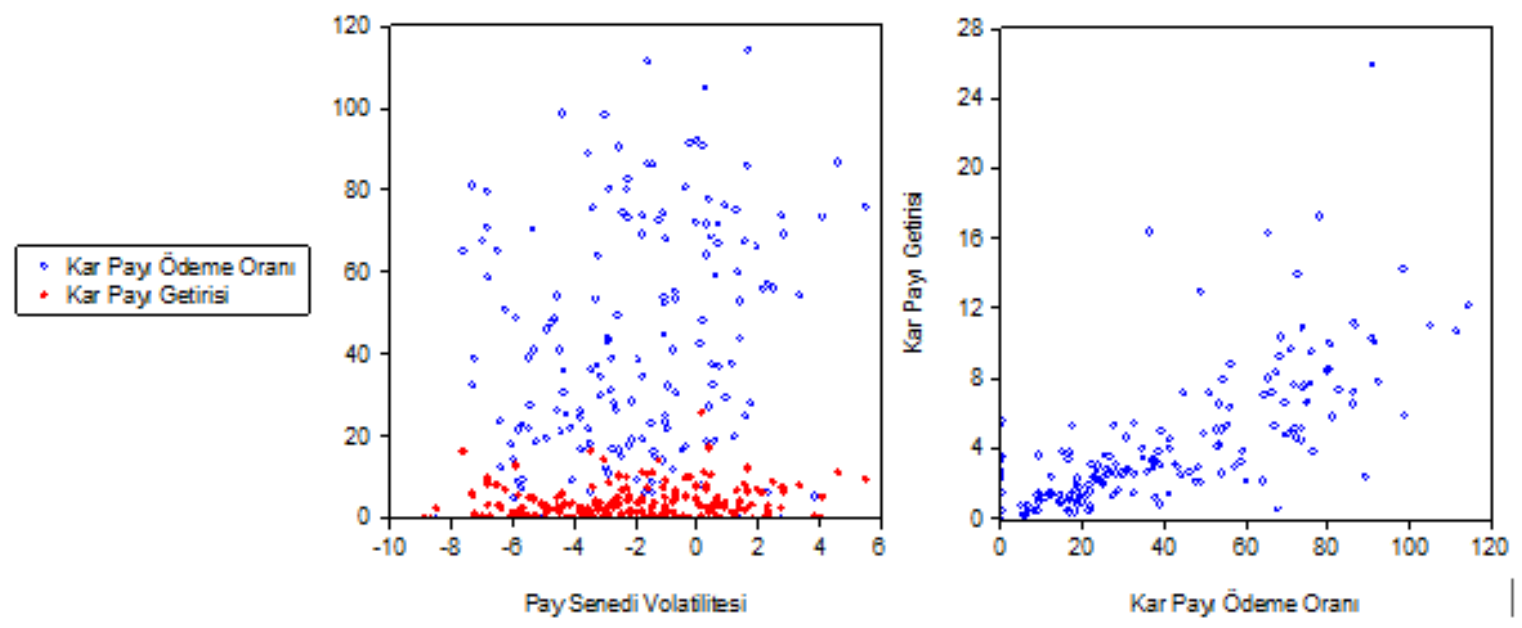

Şekil 2. Serpilme Diyagramları

Serpilme diyagramları, değişkenler arasındaki ilişkiyi belirlemek için kullanılmakta ancak değişkenler arasındaki ilişkinin sebebini göstermemektedir. Şekil 2'de değişkelere ilişkin serpilme diyagramları incelendiğinde, verilerin dağınık bir dağılım gösterdiği ve negatif ya da pozitif bir seyir izlemediği gözlemlenmektedir. Değişkenler arasında içsellik ve çoklu doğrusal bağlantı sorununun olup olmadığı Spearman korelasyon analizi ve VIF testi ile araştırılmıştır. Spearman korelasyon analizine ilişkin sonuçlar Tablo 4'te gösterilmektedir.

Tablo 4. Spearman Korelasyon Test Sonuçları

\begin{tabular}{|c|r|r|r|}
\hline \multicolumn{3}{|l|}{$\begin{array}{l}\text { Korelasyon } \\
\text { t-İstatistik } \\
\text { Olas1lik }\end{array}$} \\
\hline & \multicolumn{1}{|c|}{ PSV } & \multicolumn{1}{c|}{ KG } & KÖO \\
\hline PSV & 1,000000 & & \\
\hline & ----- & & \\
\cline { 2 - 4 } & ----- & & \\
\hline KG & 0,159620 & 1,000000 & \\
\hline & 2,275225 & ----- & \\
\cline { 2 - 4 } & 0,0240 & ---- & \\
\hline KÖO & 0,212972 & 0,758110 & 1,000000 \\
\hline & 3,067151 & 16,35812 & ----- \\
\cline { 2 - 4 } & 0,0025 & 0,0000 & ----- \\
\hline
\end{tabular}

Değişkenler arasında hesaplanan korelasyon katsayısının 0,75 'den fazla olması panel veri analizinde istenmeyen durumdur (Albayrak, 2005). Spearman korelasyon test sonuçları incelendiğinde en yüksek korelasyon ilişkisi kâr payı getirisi ve kâr payı ödeme oranı değişkenleri arasında 0,75 olarak hesaplanmıştır. Bu kapsamda değişkenler arasında içsellik ve çoklu doğrusal bağlantı sorunun olmadığı söylenebilmektedir. Bağımsız değişkenlere ilişkin VIF testi sonuçları Tablo 5'te gösterilmektedir. 
Tablo 5. VIF Testi Sonuçları

\begin{tabular}{|c|c|c|c|}
\hline Değişken & $\begin{array}{c}\text { Varyans } \\
\text { Katsayısı }\end{array}$ & $\begin{array}{c}\text { Merkezi } \\
\text { Olmayan VIF }\end{array}$ & $\begin{array}{c}\text { Merkezi } \\
\text { VIF }\end{array}$ \\
\hline KÖO & 0,000107 & 5,595758 & 2,351455 \\
\hline KG & 0,006236 & 4,556103 & 2,351455 \\
\hline C & 0,099086 & 2,393933 & NA \\
\hline
\end{tabular}

VIF değerleri incelendiğinde her iki değişken içinde 10'dan küçük gerçekleştiği gözlemlenmektedir. Bu doğrultuda değişkenler arasında çoklu doğrusal bağlantı sorununun olmadığını VIF testi sonuçları da desteklemektedir.

Seriler arasında yatay kesit bağımlılı̆̆ının bulunması ve bu durum dikkate alınmadan analiz yapılması analiz sonuçlarında tutarsız sonuçlar elde edilmesine sebep olabilmektedir (Breusch- Pagan, 1980; Pesaran, 2004). Çalışmada, zaman boyutu yatay kesit boyutundan büyük olduğu için hem panel bazında hem de değişken bazında yatay kesit bağımlılığı analizinde Ullah ve Yagamata (2008) LMadj testi kullanılmıştır. Test sonuçları Tablo 6'da gösterilmektedir.

Tablo 6. Yatay Kesit Bağımlılığı Test Sonuçları

\begin{tabular}{|c|c|c|c|}
\hline Gösterge & Test & İstatistik & Olasılık \\
\hline Model & LMadj PUY, 2008 & 29,595 & 0,000 \\
\hline PSV & LMadj PUY, 2008 & 5,438 & 0,000 \\
\hline KÖO & LMadj PUY, 2008 & 2,204 & 0,014 \\
\hline KG & LMadj PUY, 2008 & $-5,512$ & 0,696 \\
\hline \multicolumn{4}{|c|}{$\begin{array}{l}\mathbf{H}_{\mathbf{0}}: \text { Yatay Kesit Bağımlılığ } 1 \text { yoktur. } \\
\mathbf{H}_{1}: \text { Yatay Kesit Bağımlılığ } 1 \text { vardır. }\end{array}$} \\
\hline $\begin{array}{l}\text { NOT: Pay Senedi Vo } \\
\text { Oranı (KÖO) ile göst }\end{array}$ & $\begin{array}{l}\text { PSV), Kar Payı Getiı } \\
\text { ir. }\end{array}$ & $\mathrm{KG})$, Kar $\mathrm{F}$ & yı Ödeme \\
\hline
\end{tabular}

Tablo 6 test sonuçları incelendiğinde model bazında ve PSV, KÖO değişkenlerinde hesaplanan olasılık değeri kritik değer olan 0,05'ten küçük, KG değişkeninde ise hesaplanan olasılık değeri kritik değer olan 0,05'ten büyük gerçekleşmiştir. Bu doğrultuda panel bazında ve PSV, KÖO değişkenlerinde yatay kesit bağımlılığı söz konusu iken KG değişkeninde yatay kesit bağımlılığı yoktur. Bu nedenle birim kök sınaması yapılırken yatay kesit bağımlılığı sorunu olan değişkenler için yatay kesit bağımlılığını dikkate alan ikinci nesil testler, yatay kesit bağımlılığ sorunu olmayan değişken için ise birincil nesil testler kullanılmıştır. Panel veri analizinde birim kök testlerinin belirlenmesinde homojenlik sınaması ile karar verilebilmektedir. Homojenlik test sonuçları Tablo 7’de gösterilmektedir.

Tablo 7. Homojenlik/Heterojenlik Test Sonuçları

\begin{tabular}{|l|c|c|c|c|}
\hline Değişkenler & $\widetilde{\boldsymbol{\Delta}}$ & Olasılık & $\widetilde{\boldsymbol{\Delta}}_{\text {adj }}$ & Olasılık \\
\hline PSV & 2,120 & 0,017 & 2,299 & 0,011 \\
\hline KÖO & 1,808 & 0,035 & 1,961 & 0,025 \\
\hline KG & 1,564 & 0,059 & 1,696 & 0,045 \\
\hline Ho: Eğim katsayıları homojendir \\
\hline
\end{tabular}


Tablo 7’de yer alan delta testi sonuçlarına göre, bütün değişkenler için hesaplanan delta olasılık değerleri kritik değer olan 0,05'ten küçük gerçekleşmiştir. Bu doğrultuda eğim katsayıları homojendir olan sıfır hipotezi reddedilmektedir. Dolayısıyla değişkenlerin eğim katsayılarının heterojen olduğu sonucuna ulaşılmıştır. Yatay kesit bağımlılığ ve homojenlik test sonuçları doğrultusunda serilerin durağanlıkları PSV ve KÖO değişkenleri için Bai ve Ng (2004) PANIC ve Hadri ve Kurozumi (2012) HK Panel-KPSS testi testleri ile KG değişkeni için ise Im, Pesaran ve Shin (2003) IPS, Philips ve Perron (1988) PP ve Dickey ve Fuller (1981) ADF testleri ile incelenmiştir. Birim kök testleri öncesi gözlem grafikleri Şekil 3'te gösterilmektedir.

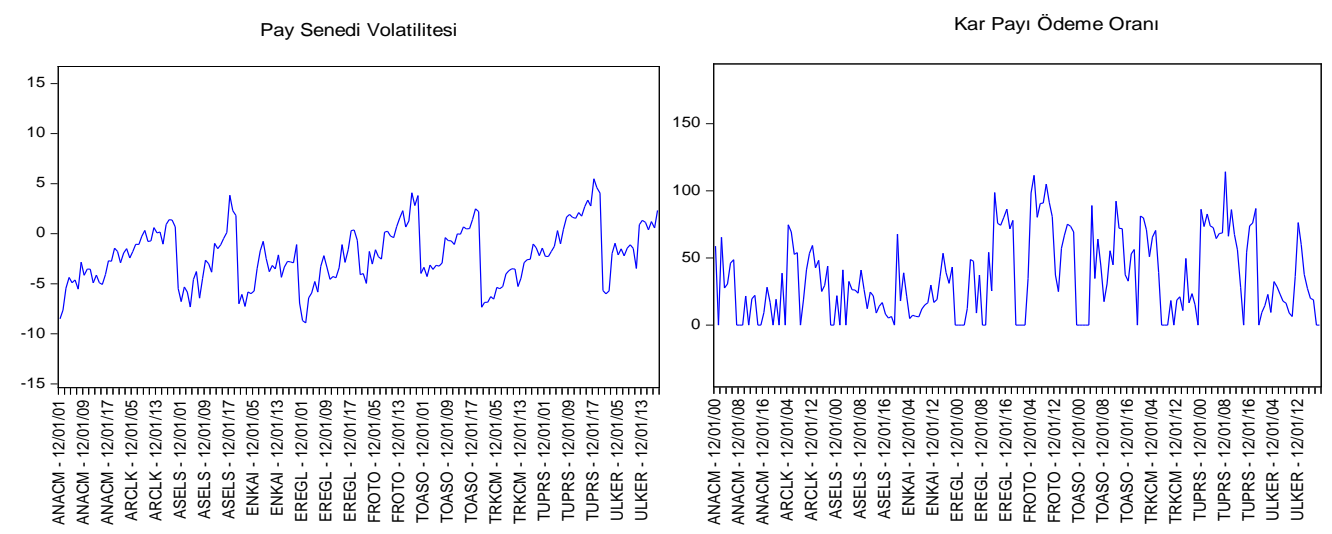

Kar Payı Getirisi

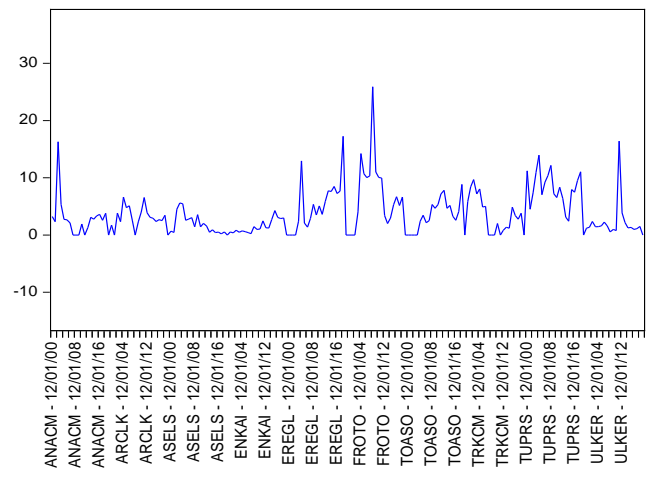

Şekil 3. Birim Kök Öncesi Gözlem Grafikleri

Değişkenlere ilişkin grafikler incelendiğinde, değişkenlerin ortalama değer aralığında artış veya azalış gösterdiği ve birim kök içermediği gözlemlenmektedir. Bu durum birim kök testleri ile desteklenmelidir. Dolayısıyla, PSV ve KÖO değişkenleri için ilk olarak PANIC testi yapılmıştır. PANIC birim kök testi Tablo 8'de gösterilmektedir. 
Tablo 8. PANIC Birim Kök Test Sonuçları

\begin{tabular}{|rcccc|}
\hline \multirow{2}{*}{ Seviye } & \multicolumn{2}{c}{ Sabit } & \multicolumn{2}{c|}{ Sabit ve Trend } \\
\cline { 2 - 5 } & İstatistik & Olas1lik D. & İstatistik & Olas1lık D. \\
\hline PSV & & & & \\
\hline$Z_{\hat{e}}^{c}$ & 2,2122 & 0,0135 & 2,4666 & 0,0068 \\
$P_{\hat{e}}^{c}$ & 33,9910 & 0,0262 & 35,6003 & 0,0171 \\
KÖO & & & & \\
\hline$Z_{\hat{e}}^{c}$ & 2,1216 & 0,0169 & 4,6070 & 0,0000 \\
$P_{\hat{e}}^{c}$ & 33,4184 & 0,0303 & 49,1374 & 0,0003 \\
\hline
\end{tabular}

Tablo 8'de yer alan test sonuçları incelendiğinde her iki değişken için hesaplanan olasılık değerinin kritik değer olan 0,05 'ten küçük olduğu görülmüştür. Dolayısıyla birim kökün varlığını ifade eden sıfır hipotezi reddedilmektedir. Her iki değişkenin de durağan olduğu tespit edilmiştir. PSV ve KÖO değişkenlerinin birim kök içerip içermediğini araştırmak için yapılan bir diğer test Hadri ve Kurozumi (2012) HK Panel-KPSS testidir. Tablo 9'da Hadri ve Kurozumi birim kök test sonuçları gösterilmektedir.

Tablo 9. Hadri \& Kurozumi Test Sonuçları

\begin{tabular}{|lllll|}
\hline \multirow{2}{*}{ Seviye } & \multicolumn{2}{c}{ Sabit } & \multicolumn{2}{c|}{ Sabit ve Trend } \\
\cline { 2 - 5 } & İstatistik & Olas1lik D. & İstatistik & Olas1lik D. \\
\hline PSV & & & & \\
\hline Za_spac & $-2,2125$ & 0,9865 & $-0,8666$ & 0,8069 \\
Za_la & $-1,9066$ & 0,9717 & $-1,1174$ & 0,8681 \\
KÖO & & & & \\
\hline Za_spac & 0,5656 & 0,2858 & 0,6044 & 0,2728 \\
Za_la & 1,4327 & 0,0760 & 1,4840 & 0,0689 \\
\hline
\end{tabular}

Hadri ve Kurozumi birim kök testi sıfir hipotezi diğer birim kök testlerinden farklı olarak "birim kök yoktur" şeklindedir. Bu doğrultuda test sonuçları incelendiğinde her iki değişken için de hesaplanan olasılık değerleri kritik değer olan 0,05 'ten büyük hesaplanmış ve sıfır hipotezi kabul edilmiştir. Dolayısıyla her iki değişken de düzeyde durağandır. KG değişkeni yatay kesit bağımlılığı sorunu içermediği için birim kökün varlığı birincil nesil testler olan IPS, ADF ve PP testleri ile araştırılmıştır. Test sonuçları Tablo 10'da gösterilmektedir. 
Tablo 10. KG Değişkeni için IPS, ADF ve PP Test Sonuçları

\begin{tabular}{|c|c|c|c|}
\hline & Test & t-istatistiği & Olasılık D. \\
\hline \multirow{5}{*}{ Sabit } & IPS & $-4,08001$ & 0,0000 \\
\hline & ADF Fisher & 50,7841 & 0,0002 \\
\hline & ADF $_{\text {Choi }}$ & $-4,08961$ & 0,0000 \\
\hline & PP $P_{\text {Fisher }}$ & 49,0564 & 0,0003 \\
\hline & $\mathbf{P P}_{\text {Choi }}$ & $-3,85393$ & 0,0001 \\
\hline \multirow{5}{*}{ Sabit ve Trend } & IPS & $-4,00895$ & 0,0000 \\
\hline & ADF Fisher & 49,7610 & 0,0002 \\
\hline & ADF $_{\text {Choi }}$ & $-3,65148$ & 0,0001 \\
\hline & PPFisher & 46,9736 & 0,0006 \\
\hline & PP $_{\text {Choi }}$ & $-3,36266$ & 0,0004 \\
\hline
\end{tabular}

Tablo 10'da yer alan test sonuçları incelendiğinde bütün testler için sabit ve sabit ve trendde hesaplanan olasılık değeri 0,05'ten küçüktür. Dolayısıyla birim kökün varlığını ifade eden sıfir hipotezi reddedilmektedir. KG değişkeninin de düzeyde durağan olduğu tespit edilmiştir. Serilerin durağan olduğu belirlendikten sonra yapılacak olan tahminlemeden önce sabit etkiler ya da rassal etkiler modellerinden hangisinin tahminleme için kullanılacağına, $\mathrm{F}$ testi, Breuch-Pagan LM (1980) ve Honda (1985) testleri ile karar verilmiştir. Testlere ilişkin analiz sonuçları Tablo 11'de gösterilmektedir.

Tablo 11. Tahmin Modeli Belirleme Analiz Sonuçları

\begin{tabular}{|c|c|c|c|}
\hline Test & İsta. & p-değeri & Hipotez \\
\hline $\begin{array}{l}\text { F-grup_sabit } \\
\text { F-zaman_sabit } \\
\text { F-iki yönlü_sabit }\end{array}$ & $\begin{array}{l}58,46348 \\
36,06199 \\
44,38392\end{array}$ & $\begin{array}{l}0,000000 \\
0,000000 \\
0,000000\end{array}$ & $\begin{array}{l}\mathrm{H}_{0}: \text { Kesit etkisi varken zaman etkisi yoktur. } \\
\mathrm{H}_{0} \text { :Zaman etkisi varken kesit etkisi yoktur. } \\
\mathrm{H}_{0}: \text { Kesit ve zaman etkisi yoktur }\end{array}$ \\
\hline $\begin{array}{l}\text { LM-grup_rassal } \\
\text { LM-zaman_rassal } \\
\text { LM- iki yönlü_rassal }\end{array}$ & $\begin{array}{l}191,0765 \\
180,7032 \\
371,7797\end{array}$ & $\begin{array}{l}0,000000 \\
0,000000 \\
0,000000\end{array}$ & $\begin{array}{l}\mathrm{H}_{0}: \text { Kesit etkisi varken zaman etkisi yoktur. } \\
\mathrm{H}_{0} \text { :Zaman etkisi varken kesit etkisi yoktur. } \\
\mathrm{H}_{0} \text { :Kesit ve zaman etkisi yoktur }\end{array}$ \\
\hline $\begin{array}{l}\text { Honda-grup_rassal } \\
\text { Honda-zaman_rassal } \\
\text { Honda-iki yönlü_rassal }\end{array}$ & $\begin{array}{l}13,82304 \\
13,44259 \\
19,27971\end{array}$ & $\begin{array}{l}0,000000 \\
0,000000 \\
0,000000\end{array}$ & $\begin{array}{l}\mathrm{H}_{0}: \text { Kesit etkisi varken zaman etkisi yoktur. } \\
\mathrm{H}_{0} \text { :Zaman etkisi varken kesit etkisi yoktur. } \\
\mathrm{H}_{0} \text { :Kesit ve zaman etkisi yoktur }\end{array}$ \\
\hline
\end{tabular}

Tablo 11'de yer alan $\mathrm{F}$ testi sonuçları incelendiğinde modelde grup ve zaman etkilerinin olduğu ve çift yönlü sabit etkiler modelinin kullanılmasının daha etkin sonuçlar vereceği tespit edilmiştir. LM ve Honda test sonuçları incelendiğinde ise havuzlanmış model yerine rassal etkiler modelinin geçerli olduğu belirlenmiştir. Çalışmada kullanılan veriler belirli bir gruptan seçilmiş ve belirli bir döneme dayanıyorsa, modelin nihai tahmininde sabit etkiler modeli tercih edilmelidir (Baltagi, 2005: 12). Bu doğrultuda model tahmininde sabit etkiler modeli tercih edilmiştir. Sabit etkiler modeli tercih edilerek, Breusch-Pagan-Godfrey LM testi ile değişen varyans ve Baltagi ve Li (1991), Born ve Bretuing (2016) ve DurbinWatson testleri ile de otokorelasyon sınanmıştır. Test sonuçları Tablo 12'de gösterilmektedir. 
Tablo 12. Sabit Etkiler Modeli İçin Değişen Varyans ve Otokorelasyon Test Sonuçları

\begin{tabular}{|l|c|c|}
\hline \multicolumn{3}{|c|}{ Değişen Varyans } \\
\hline Breusch-Pagan-Godfrey LMh_fixed & 41,24814 & 0,000000 \\
\hline $\mathrm{H}_{0}$ : Değişen Varyans yoktur & \\
$\mathrm{H}_{1}$ : Değişen Varyans vardır & Otokorelasyon \\
\hline \multicolumn{3}{|c|}{1,043927} \\
\hline Baltagi ve Li (1991) LMp-stat & 40,51737 & 0,000000 \\
\hline Born ve Bretuing (2016) LMp*-stat & 50,68590 & 0,000000 \\
\hline Durbin-Watson & \multicolumn{2}{c|}{} \\
\hline $\mathrm{H}_{0}$ : Otokorelasyon yoktur & \multicolumn{1}{|c|}{} \\
$\mathrm{H}_{1}$ : Otokorelasyon vardır
\end{tabular}

Tablo 12'de yer alan Breusch-Pagan-Godfrey LM test değerleri incelendiğinde hesaplanan olasılık değerinin 0.05 kritik değerinden küçük olduğu tespit edilmiş ve sıfir hipotezi reddedilmiştir. Modelde değişen varyans sorunu söz konusudur. Baltagi ve Li (1991) LM ve Born ve Bretuing LM (2016) testleri değerleri incelendiğinde hesaplanan olasıllı değerinin 0.05 kritik değerinden küçük olduğu tespit edilmiş ve sıfir hipotezi reddedilmiştir. Modelde otokorelasyon sorunu söz konusudur. DW test sonucu Baltagi ve Li (1991) LM ve Born ve Bretuing LM (2016) testleri sonuçlarını destekler niteliktedir. Değişen varyans ve otokorelasyon sorunlarının varlığı durumunda dirençli tahminciler ile tutarlı sonuçların alınması sağlanmaktadır.

Modelde dirençli tahminciler kullanılarak model tahmini yapılmış ve en iyi sonucu veren Beck ve Katz (1995) tarafından geliştirilen Period SUR (PCSE) yöntemi tercih edilmiştir. Tahmin sonuçları, Tablo 13 'te sunulmaktadır.

Tablo 13. Panel Veri Analiz Sonuçları

\begin{tabular}{|c|c|c|c|c|}
\hline \multicolumn{5}{|c|}{$\begin{array}{l}\text { Bağımlı Değişken: PSV } \\
\text { Yöntem: Period SUR (PCSE) } \\
\text { Örneklem: 12/01/2000- 12/01/2019 }\end{array}$} \\
\hline Değişken & Katsayı & Std. Hata & t-İstatistiği & Prob. \\
\hline KÖO & 0,006636 & 0,003850 & 1,723821 & $0,0866^{*}$ \\
\hline KG & $-0,055731$ & 0,031101 & $-1,791962$ & $0,0749^{*}$ \\
\hline C & $-2,170888$ & 0,103232 & $-21,02924$ & $0,0000^{* * *}$ \\
\hline \multicolumn{3}{|c|}{$\begin{array}{l}\text { R-Kare } \\
\text { Düzeltilmiş R-Kare } \\
\text { S.E. of regresyon } \\
\text { F-istatistik } \\
\text { Prob (F- istatistik) }\end{array}$} & \multicolumn{2}{|l|}{$\begin{array}{l}0,885721 \\
0,865435 \\
1,074779 \\
43,66125 \\
0,000000^{* * * *}\end{array}$} \\
\hline \multicolumn{5}{|c|}{$\begin{array}{l}\text { NOT 1: }{ }^{* * *},{ }^{* *} \text {, ve }{ }^{*} \text { simgeleri katsayıların sırasıyla } \% 1, \% 5 \text { ve } \% 10 \text { önem } \\
\text { düzeylerinde anlamlı olduğunu göstermektedir. } \\
\text { NOT 2: Pay Senedi Volatilitesi (PSV), Kar Payı Getirisi (KG), Kar Payı Ödeme } \\
\text { Oranı (KÖO) ile gösterilmektedir. }\end{array}$} \\
\hline
\end{tabular}

Kâr payı dağıtım kararları ile pay senedi volatilitesi ilişkisini incelemek için oluşturulan model doğrultusunda elde edilen bulgular Tablo 13'te yer almaktadır. Analiz sonuçları incelendiğginde, modelin bir bütün olarak anlamlılı̆ıını ifade eden $\mathrm{F}$ istatistik olasılık değerinin \%1 anlamlılık düzeyinde anlamlı olduğu gözlemlenmektedir. Bağımsız değişkenler 
olan KÖO ve KG değişkenleri bağımlı değişken olan PSV'deki değişimin \%88'ni $\left(\mathrm{R}^{2}\right)$ açıkladığı belirlenmiştir. Modelde KÖO değişkeni ile PSV arasında \%10 anlamlılık düzeyinde pozitif yönlü bir ilişki tespit edilirken KG değişkeni ile PSV arasında \%10 anlamlılık düzeyinde negatif yünlü bir ilişki tespit edilmiştir. Bu doğrultuda kâr payı ödeme oranında meydana gelen bir birimlik artış pay senedi volatilitesinde 0,006 birimlik artışa yol açmaktadır. Kâr payı getirisinde meydana gelen bir birimlik artış ise pay senedi volatilitesinde 0,055 birimlik azalışa yol açmaktadır. Dolayısıyla araştırma kapsamında kurgulanan Hipotez 1 ve Hipotez 2'de $\mathrm{H}_{1}$ hipotezi kabul edilmektedir. Analiz doğrultusunda elde edilen bulgular Nguyen vd., (2020), Nguyen vd., (2019), Haque vd., (2018), Cristea ve Cristea (2018), Hooi vd., (2015), Ramadan (2013), Hashemijoo ve Ardekani (2012) tarafindan yapilan çalışmalarda elde edilen bulgular ile benzerlik göstermektedir. Sonuçlar değerlendirildiğinde kâr payı getirisi ne kadar yüksek ise volatilitenin daha düşük olduğu, dolayısıyla kâr payı getirisi arttığında pay senedi fiyatının oynak değil daha istikrarlı seyir izlediği ve bu durumun riski düşürdüğü gözlemlenmektedir. Kâr payı ödeme oranı yükseldiğinde pay senedi volatilitesi arttığı dolayısıyla oranın yükselmesinin riski yükselttiği söylenebilmektedir.

\section{SONUÇ}

Kâr payı dağıtım kararlarının firma hakkında bilgi verme özelliği pay fiyatlarına olan talebi etkilemektedir. Bu durum firmaların pay fiyatlarında artış veya azalışa yol açabilmekte ve pay fiyatlarında volatiliteye sebep olmaktadır. Pay fiyatlarındaki volatilite yatırımcıların maruz kaldıkları riskin göstergesi olup, pay piyasalarının volatilitesini etkileyen faktörler önem arz etmektedir. Bu kapsamda, çalışmada, BİST 50 endeksinde 2000-2019 döneminde devamlı olarak işlem gören firmaların kâr payı politikaları ile pay senedi volatilitesi arasındaki ilişki araştırılmıştır.

Çalışmada bağımsız değişken olarak kâr payı getirisi ve kâr payı ödeme oranı, bağımlı değişken olarak ise pay senedi volatilitesi analize dahil edilmiştir. Yapılan panel veri analizi sonucunda, kâr payı ödeme oranı ile pay senedi volatilitesi arasında istatistiksel olarak anlamlı pozitif yönlü ilişki tespit edilirken, kâr payı getirisi ile pay senedi volatilitesi arasında istatistiksel olarak anlamı negatif yönlü ilişki tespit edilmiştir. Dolayısıyla araştırma kapsamında kurgulanan Hipotez 1 ve Hipotez 2'de $\mathrm{H}_{1}$ hipotezi kabul edilmektedir. Kurgulanan hipotezler doğrultusunda kâr payı getirisi arttığında pay senedi volatilitesinin düştüğü, ancak kâr payı getiri oranı arttığında pay senedi volatilitesinin yükseldiği tespit edilmiştir. Yatırımcıların kâr payı getirisine göre kâr payı oranında meydana gelen gelişmeleri daha riskli gördükleri bu nedenler orandaki değişimin riski artırdı̆̆ı söylenebilmektedir. Yatırımcıların istikrarlı temettü politikası izleyen firmalara yatırım yapmak istemeleri, kâr payı getiri oranındaki değişimin pay senedi volatilitesini negatif etkilemesini açıklar niteliktedir. Çalışmada elde edilen bulgular Nguyen vd., (2020), Nguyen vd., (2019), Haque vd., (2018), Cristea ve Cristea (2018), Hooi vd., (2015), Ramadan (2013), Hashemijoo ve Ardekani (2012) tarafından yapılan çalışmalarda elde edilen bulgular ile benzerlik göstermektedir. Yapılan çalışmaların uygulama alanı Vietnam, Romanya, Malezya ve Ürdün ülkelerinde gerçekleşmiştir. Bu kapsamda çalışmanın sonuçlarının farklı ülkeler ve sektörler üzerinde yapıldığı göz önünde bulundurulduğunda gelişmekte olan ülkeler ile benzer sonuçlar verdiği gözlemlenmektedir. Bu kapsamda gelişmekte olan ülkelerde kâr payı dağıtım kararlarının bilgi verme özelliği olduğu piyasalarda bilginin fiyata tam yansımamış olduğu söylenebilmektedir. 
Elde edilen bulgulara göre kâr payı getirisi ne kadar yüksek ise volatilitenin daha düşük olduğu, dolayısıyla kâr payı getirisi arttığında pay senedi fiyatının oynak değil daha istikrarlı seyir izlediği ve bu durumun riski düşürdüğü gözlemlenmektedir. Kâr payı ödeme oranı yükseldiğinde ise volatilite dolayısıyla risk yükselmektedir. Kâr payı ödemelerine ilişkin bilgiler yatırımcılar için bilgi sağlamakta, firmaların gelecekteki kâr payı dağıtım politikalarını, karlılı̆ııı, finansal performansını tahmin etmelerine yardımcı olmakta ve pay senedine olan talebi etkilemektedir. Bu doğrultuda kâr payı politikalarına ilişsin bilgilerin pay senedi volatilitesini yükselten veya azaltan etkilere sebep olduğu gözlemlenmektedir. Sonuçlar değerlendirildiğinde kâr payı dağıtımlarının bilgi verme özelliğinin pay senedi fiyatlarını etkilediği dolayısıyla piyasanın etkin olmadığı, sinyal teorisi ve müşteri etkisi teorisinin geçerli olduğu söylenebilmektedir.

Çalışmanın sonuçları, firma yöneticileri ve yatırımcılar açısından önem arz etmektedir. Her firmanın benimsediği kâr payı dağııım politikası farklıdır. $\mathrm{Bu}$ doğrultuda firma yöneticileri kâr payı politikaları ile pay senedine olan talebi dolayısıyla pay senedi fiyatını ve firma değerini etkileyebileceklerdir. Çalışmanın sonuçlarına göre firma yöneticilerinin istikrarlı kâr payı ödeme oranı sağlamaları ile pay senedi volatilitesinde düşüş̧ sağlayabileceklerdir. Yatırımcılar ise kâr payı politikaları ile ilgili daha fazla bilgiye sahip olarak yatırımlarında maruz kalacakları riski düşürebileceklerdir.

\section{KAYNAKLAR}

Agbatogun, Taofeek O. - Kajola, Sunday O. - Akinbola, Olufemi A. (2019), "Influence of Dividend Policy on Stock Price Volatility of Non-Financial Firms Listed Nigerian Stock Exchange”, Izvestiya Journal of Varna University of Economics, 63(1), pp. 3549.

Al-Shawawreh, Fawaz K. (2014), "The Impact of Dividend Policy on Share Price Volatility: Empirical Evidence from Jordanian Stock Market”, European Journal of Business and Management, 6(38), pp. 133-143.

Albayrak, Ali S. (2005), “Çoklu Doğrusal Bağlantı Halinde En küçük Kareler Tekniğinin Alternatifi Yanlı Tahmin Teknikleri ve Bir Uygulama”, ZKÜ Sosyal Bilimler Dergisi, 1(1), ss. 105-107.

Allen, Dave E. - Rachim, Veronica S. (1996), "Dividend Policy and Stock Price Volatility: Australian Evidence”, Applied Financial Economics, 6(2), pp. 175-188.

Bai, Jushan - Ng, Serena (2004), “A Panic Attack on Unit Roots and Cointegration”, Econometrica, 72, pp. 1127-1177.

Baltagi, Badi H., (2005) Econometric Analysis Of Panel Data, England: John Wiley\&Sons, Ltd.

Baltagi, Badi H.- Li, Qi, (1991) "A Joint Test For Serial Correlation And Random Individual Effects”, Statistics and Probability Letters, 11(3), pp. 277-280. 
Baskin, Jonathan, (1989) “Dividend Policy and The Volatility of Common Stocks”, The Journal of Portfolio Management, 15(3), pp. 19-25.

Beck, Nathaniel - Katz, Jonathan N. (1995), "What To Do (And Not To Do) With TimeSeries Cross-Section Data”, American Political Science Review, 89(3), pp. 634-647.

Born, Benjamin - Breitung, Jörg (2016), “Testing For Serial Correlation In Fixed-Effects Panel Data Models”, Econometric Reviews, 35(7), pp. 1290-1316.

Breusch, Trevor S. - Pagan, Adrian (1980), “The Lagrange Multiplier Test and Its Applications to Model Specification in Econometrics” Review of Economic Studies, 47(1), pp. 239-253.

Cristea, Ciprian - Cristea, Maria (2018), “The Influence of Dividend Policy on The Volatility of Shares in The Romanian Equity Capital Market”, Annual Session of Scientific Papers IMT ORADEA.

Dhaliwal, Dan S. - Ericson, Merle - Trezevant, Robert (1999), “A Test of the Theory of Tax Clienteles for Dividend Policies”, National Tax Journal, 52(2), pp. 179-194.

Diacogiannis, George P. (1993) Financial Management a Modelling Approach Using Spreadsheets. McGraw-Hill.

Dickey, David A. - Fuller, Wayne A. (1981) "Likelihood Ratio Statistics for Autoregressive Time Series with A Unit Root” Econometrica, 49, pp. 1057-1072.

Dionne, Georges - Ouederni, Karima (2011), “Corporate Risk Management and Dividend Signaling Theory”, Finance Research Letters, 8, pp. 188-195.

Eraslan, Mehmet - Koç, Selahattin (2017), "Kâr Payı Ödemelerinin Hisse Başına Kâra Etkisinin Analizi: BİST Çimento Sektöründe Bir Uygulama”, Injosos Al-Farabi International Journal on Social Sciences/ Al-Farabi Uluslararası Sosyal Bilimler Dergisi, 1(2), ss. 158-180.

Frankfurter, George M. - Wood, Bob G. (2002), "Dividend Policy Theories and Their Empirical Tests”, International Review of Financial Analysis, 11, pp. 111-138.

Günalp, Burak - Kadıoğlu, Eyüp - Kılıç, Saim (2010), "Nakit Temettü Bilgisinin Hisse Senedi Getirisi Üzerinde Önemli Bir Etkisi Olup Olmadığının İMKB'de Test Edilmesi”, Hacettepe Üniversitesi İktisadi ve İdari Bilimler Fakültesi Dergisi, 28(2), ss. 47-69.

Gürel, Eymen - Beyazıtlı, Ercan (2017), "Kar Payı Verimi ve Borsa İstanbul A.Ş. Üzerinde bir Uygulama”, Kırklareli Üniversitesi İktisadi ve İdari Bilimler Fakültesi Dergisi, 6(2), ss. 121-133.

Habib, Yasir - Kiani, Zernigah, I. - Khan, Muhammad A. (2012), “Dividend Policy and Share Price Volatility: Evidence from Pakistan”, Global Journal of Management and Business Research, 12(5). 
Haque, Rumana - Jahiruddin, A.T.M. - Mishu, Farhana (2018), "Dividend Policy and Share Price Volatility: A Study on Dhaka Stock Exchange”, Australian Academy of Accounting and Finance Review, 4(3), pp. 89-99.

Hashemijoo, Mohammad - Ardekani, Aref M. - Younesi, Nejat (2012), "The Impact of Dividend Policy on Share Price Volatility in the Malaysian Stock Market”, Journal of Business Studies Quarterly, 4(1), pp. 111-129.

Honda, Yuzo (1985), "Testing The Error Components Model With Non-Normal Disturbances”, Review of Economic Studies. 52(4), pp. 681-690.

Hooi, Sew E. - Albaity, Mohamed - Ibrahimy, Ahmad I. (2015), "Dividend Policy and Share Price Volatility”, Investment Management and Financial Innovations, 12(1), pp. 226234.

Hussainey, Khaled - Mgbame, Chijoke O. - Chijoke-Mgbame, Aruoriwo M. (2011), "Dividend Policy and Share Price Volatility: UK Evidence", The Journal of Risk Finance, 12(1), pp. 57-68.

Im, Kyung - Pesaran, Hashem - Shin Yongcheol (2003), "Testing for Unit Roots in Heterogeneous Panels”, Journal of Econometrics, 115, pp. 53-74.

Jahfer, Athambawa - Mulafara, Hameed (2016), "Dividend Policy and Share Price Volatility: Evidence from Colombo Stock Market”, Int. J. Managerial and Financial Accounting, 8(2), pp. 97-108.

Kaderli, Yusuf - Başkaya, Hatice (2014), "Halka Açık Firmalarda Kâr Payı Dağıtım Duyurularının Hisse Senedi Fiyatlarına Etkisinin Ölçülmesi: Borsa İstanbul'da Bir Uygulama”, Adnan Menderes Üniversitesi Sosyal Bilimler Enstitüsü Dergisi, 1(1), pp. 49-64.

Kar, Ahmet - Özer, Özlem - Şantaş, Fatih - Budak, Fatih (2012) "Kar Dağıtımının Hisse Senedi Değeriyle İlişskisi: Spor Hizmetleri Sektörü Üzerine Bir Uygulama”, Ekonomi Bilimleri Dergisi, 4(1), pp. 1-9.

Khan, Muhammad Y. - Khan, Wajid - Bassam, Mohammed W.H.A. - Javeed, Anam (2017), "Dividend Policy and Share Price Volatility "Evidence from Karachi Stock Exchange”, Elk Asia Pacific Journal of Finance and Risk Management, 8(1).

Lashgari, Zahra - Ahmadi, Mousa (2014), "The Impact of Dividend Policy on Stock Price Volatility in The Tehran Stock Exchange" Kuwait Chapter of Arabian Journal of Business and Management Review, 3(10), pp. 273-283.

M'rabet, Rachid - Boujjat, Wiame (2016), "The Relationship Between Dividend Payments And Firm Performance: A Study Of Listed Companies in Morocco”, European Scientific Journal, 12(4), 469-482. 
Nguyen Duy T. - Bui, Mai H. - Do, Dung H. (2019), “The Relationship of Dividend Policy and Share Price Volatility: A Case in Vietnam”, Annals of Economic and Finance, 20(1), pp. 123-136.

Nguyen, Hieu - Nguyen, Anh H. - Tran, Quang C. - Le, Quynh L. (2020), "Dividend Policy and Share Price Volatility: Empirical Evidence from Vietnam Thanh”, Accounting, 6, pp. 67-78.

Pesaran, M. Hashem (2004), “General Diagnostic Tests For Cross Section Dependence In Panels”, Cambridge Working Papers in Economics, 435.

Pesaran, M. Hashem- Ullah, Aman - Yamagata, Takashi (2008), “A Bias Adjusted LM Test Of Error Cross Section Independence”, Econometrics Journal, 11(1), pp. 105-127.

Phillips, Petter C.- Perron, Pierre (1988), "Testing for a Unit Root in Time Series Regression”, Biometrika, 75, pp. 335-346.

Ramadan, Zeyad I. (2013), "Dividend Policy and Price Volatility. Empirical Evidence from Jordan”, International Journal of Academic Research in Accounting, Finance and Management Sciences, 3(2), pp. 15-22.

Ross, Stephan A. - Westerfield, Randolph W. - Jaffe, Jeffrey (2005), Corporate Finance, New York: McGraw Hill.

Süsay, Aynur - Tanrı̈ven, Cihan (2018), “BİST’te Fiyat Oynaklığı Üzerine Kar Payı Dağıtımının Etkisi” İşletme Araştırmaları Dergisi, 10(1), ss. 103-118.

Van Horne, James C., - Wachowicz, John M. (1997), Fundamentals of Financial Management, Prentice Hall.

Zor, İsrafil - Yılmaz Küçük, Şeyma (2019) “Kar Payı Dağıtım Duyurularının Hisse Senedi Piyasa Fiyatına Etkisi: BİST 100’de Ampirik Bir Çalışma” Hitit Üniversitesi Sosyal Bilimler Enstitüsü Dergisi, 12(1), ss. 33-48. 
